\title{
The June 2017 General Election: Welsh Labour's Success Story
}

Les Elections législatives de juin 2017 : le succès des travaillistes gallois

Stéphanie Bory

\section{OpenEdition}

\section{Journals}

Electronic version

URL: http://journals.openedition.org/rfcb/1943

DOI: $10.4000 /$ rfcb. 1943

ISSN: 2429-4373

Publisher

CRECIB - Centre de recherche et d'études en civilisation britannique

Electronic reference

Stéphanie Bory, «The June 2017 General Election: Welsh Labour's Success Story », Revue Française de Civilisation Britannique [Online], XXIII-2 | 2018, Online since 14 September 2018, connection on 30 April 2019. URL : http://journals.openedition.org/rfcb/1943; DOI : 10.4000/rfcb.1943

This text was automatically generated on 30 April 2019

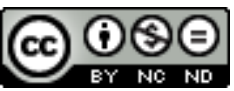

Revue française de civilisation britannique est mis à disposition selon les termes de la licence Creative Commons Attribution - Pas d'Utilisation Commerciale - Pas de Modification 4.0 International. 


\section{The June 2017 General Election: Welsh Labour's Success Story}

Les Elections législatives de juin 2017 : le succès des travaillistes gallois

\section{Stéphanie Bory}

\section{Introduction}

1 Wales has usually displayed a certain degree of difference from England in elections since the Second World War, contrary to Scotland which shared, until 1974, many similarities with England. The country represents a long-lasting Labour stronghold, since the party has won every general election for decades now, more or less ever since it took over the Liberal Party as the second largest party in the UK. Besides, for two years now, the four British nations have been led by four different parties: the Scottish National Party (SNP) in Scotland, the Democratic Unionist Party (DUP) in Northern Ireland, the Conservatives in England and Labour in Wales. Carwyn Jones, the Welsh First Minister, has become the most senior Labour politician in the UK. Yet there were some signs of decline in May 2017 when the Welsh Labour Party lost 107 seats at the local elections (from 580 to 473) while Plaid Cymru, the Welsh nationalist party, gained 33 (from 170 to 203), and, above all, the Welsh Conservative Party won 80 seats, moving from 104 to 184 . These results thus represented a clear warning to the Labour Party which was obliged to adopt a new strategy for the following snap General Election, due on 8 June. A new campaign was starting, and after a number of votes within a few years - the 2015 General Election, the 2016 Welsh elections, the Brexit referendum, the Welsh local elections - the Welsh political parties had to mobilise their electorate once more. It turned out that Welsh Labour was successful in this election, obtaining a majority of seats.

2 As a result, it is interesting to study how Welsh Labour's success story, making the Welsh Labour Party a model for the British party in London, can be explained. This paper will first analyse Welsh Labour's "fantastic results", then study Carwyn Jones's prominent role in the campaign, and finally see to what extent the Welsh Labour Party has become the real party of Wales, a role hitherto played by Plaid Cymru. 


\section{Welsh Labour's "fantastic results"}

\section{Results}

Carwyn Jones, the Welsh Labour First Minister, commenting on the results in Wales after the 8 June snap election, declared: "These are fantastic results in Wales. We had pulled out all the stops. We went out to listen to people, speak to people on the doorstep." ${ }^{1}$ Indeed, 28 seats were won by the Welsh Labour Party, representing thus a gain of 3, with $48.9 \%$ of vote share, compared with $36.9 \%$ in 2015 (see table 1).

Table 1: Results in Wales and Scotland for the 2017 general election

\begin{tabular}{|l|l|l|l|l|}
\hline Party & Seats & $\begin{array}{l}\text { Vote share } \\
2017\end{array}$ & Swing /2015 & Scotland \\
\hline Labour & $28(+3)$ & $48.9 \%$ & +12 & $7(+6)$ \\
\hline Conservative & $8(-3)$ & $33.6 \%$ & +6.4 & $13(+12)$ \\
\hline Plaid Cymru / SNP & $4(+1)$ & $10.4 \%$ & -1.7 & $35(-21)$ \\
\hline LibDems & $0(-1)$ & $4.5 \%$ & -2 & $4(+3)$ \\
\hline
\end{tabular}

SOURCE: fIGURES COMPILED BY THE AUTHOR AND BASED ON RESULTS GIVEN ON THE BBC WEBSITE.

Hence the Labour Party was clearly more successful in Wales than in Scotland, where the Conservative Party was obviously the party which benefited the most from the snap election, mostly thanks to the campaign led by Ruth Davidson, the new Tory leader in Scotland. It is interesting to compare those results with the vote shares obtained by the major parties in England and in the whole of the UK (table 2):

Table 2: Results in Wales, England, Scotland and the UK to the 8 June general election

\begin{tabular}{|l|l|l|l|l|l|l|}
\hline Party & $\begin{array}{l}\text { Wales vote } \\
\text { share }\end{array}$ & Swing & $\begin{array}{l}\text { England vote } \\
\text { share }\end{array}$ & Swing & $\begin{array}{l}\text { Scotland vote } \\
\text { share }\end{array}$ & $\begin{array}{l}\text { UK vote } \\
\text { share }\end{array}$ \\
\hline Labour & $48.9 \%$ & +12 & $41.9 \%$ & +10.3 & $27.1 \%$ & $40 \%$ \\
\hline Conservative & $33.6 \%$ & +6.4 & $45.6 \%$ & +4.6 & $28.6 \%$ & $42.4 \%$ \\
\hline LibDems & $4.5 \%$ & -2 & $7.8 \%$ & -0.4 & $6.8 \%$ & $7.4 \%$ \\
\hline
\end{tabular}

SOURCE: fIGURES COMPILED BY THE AUTHOR AND BASED ON RESULTS GIVEN ON THE BBC WEBSITE.

5 The Welsh Labour Party increased its share of votes and its number of seats for its $26^{\text {th }}$ successive General Election victory in Wales since 1922. The party obtained its highest vote share since 1997 and Tony Blair's landslide victory. There was no vote share decline in any seat in Wales. The party lost no deposit. Unsurprisingly, it obtained its highest vote 
share in Aberavon with $68.1 \%$ of votes and its lowest vote share in Montgomeryshire with $15.9 \%$ of votes. It did very well in Cardiff. And it was in Wales that the Labour Party was the most successful, even if polls were not very encouraging at first.

\section{Polls}

Comparing early and late polls reveals how the position of parties evolved during the campaign. Below is a survey of all polls carried out by ITV Wales and Cardiff University between 24 April and 7 June, i.e. the day just before the general election, since they respected the same framework. Five polls, each on vote shares and forecasts in seats, were held during the period: 24 April, 8 May, 22 May, 1 June and 7 June.

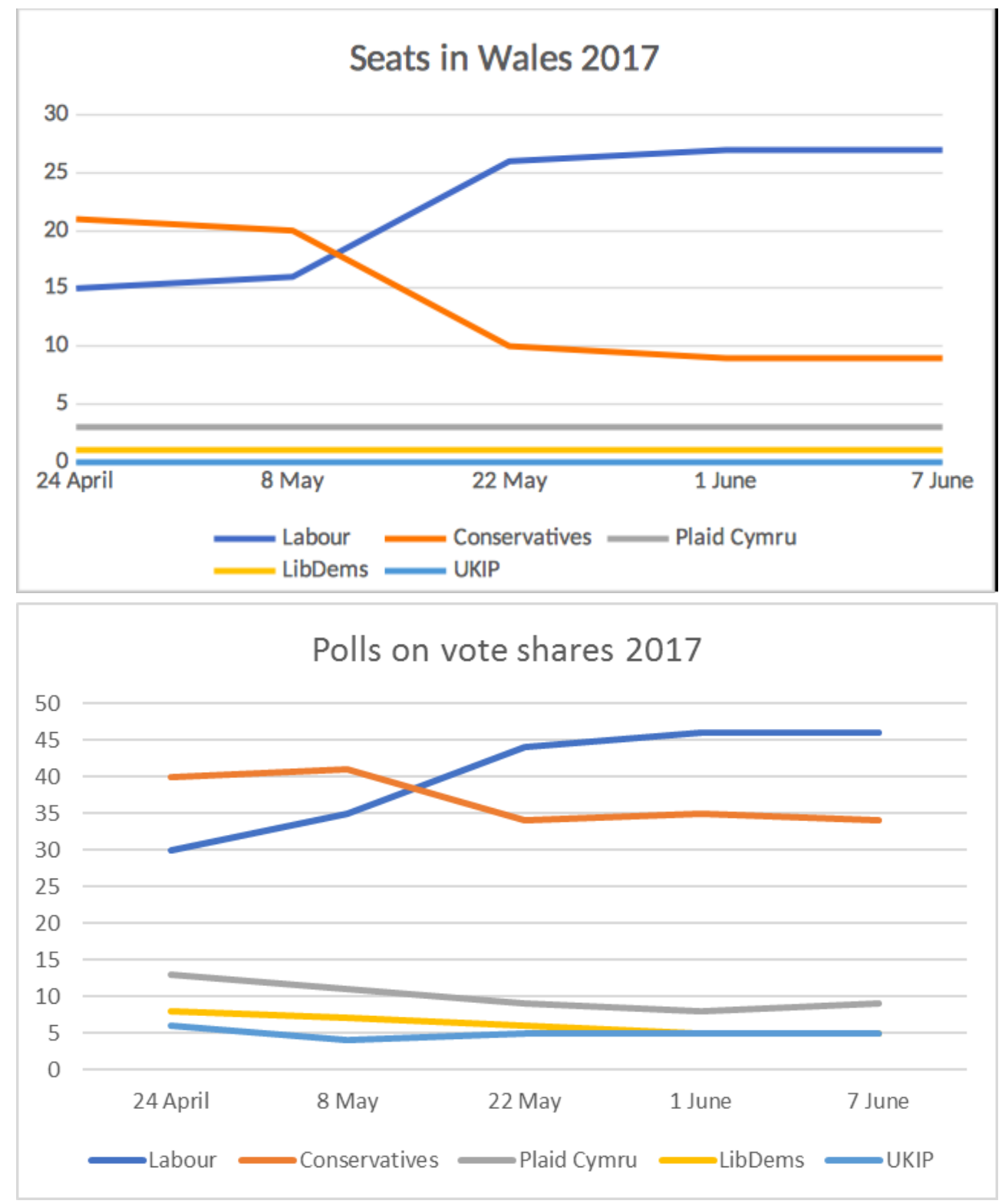

SOURCE: AUTHOR.

7 First, on 24 April, a YouGov poll for ITV Wales and Cardiff University, carried out on 1,029 people across Wales, revealed a strong lead for the Welsh Conservative Party, as indicated by the title of Martin Shipton's article on WalesOnline, "Shock poll puts the Conservatives 
ahead of Labour in Wales". He indicated: "If the poll's findings are repeated at the General Election on June 8, it would be the first time in more than a century that the Tories had won more than half of Wales' parliamentary seats". ${ }^{2}$ Considering Labour hegemony since the $1920 \mathrm{~s}$ in Wales, such results were indeed deeply surprising.

Then, on 8 May, a new Welsh political barometer was published, a poll for ITV Wales and Cardiff University on a sample of 1,018 adults across Wales in a post on Cardiff University blog by Professor Roger Scully, a member of the Wales Governance Centre (Cardiff University). The latter considered that the poll confirmed "the Conservative challenge to Labour's long-standing dominance in Wales is very real". ${ }^{3}$ It was clearly showing that Labour was fighting back in Wales but that the Conservatives were still on course for an historic victory at the general election, keeping a four-point lead.

Next, on 22 May, a poll carried out by ITV Wales and Cardiff University revealed that support for Labour in Wales had risen to $44 \%$ compared to $35 \%$ two weeks before, whereas support for the Conservative Party had declined by 7 points down to $34 \%$, the same could be seen for Plaid Cymru which was down to 9\%. Analysing the results of this new poll, Professor Roger Scully said:

The most important change from the previous poll is clearly the resurgence in Labour support. This is broadly in line with the Britain-wide polls, which have generally been showing a narrowing of the gap between the Conservatives and Labour in recent days. But the extent of the Labour rise, and Conservative fall, are rather greater in Wales, and are sufficient to put Labour back into a significant lead in Wales. ${ }^{4}$

10 According to him, trends were amplified in Wales, and were not just a mirror of the UKwide situation.

11 Next on 1 June, YouGov released another poll for ITV Wales and Cardiff University, based on 1,014 adults across Wales. On WalesOnline, a Welsh Labour spokesperson praised Welsh Labour's campaigning and canvassing, which explained, in his view, the reversal of the trends:

From day one of this election, Welsh Labour have fought hard for every vote right across Wales, in a positive campaign led from the front by our leader, Carwyn Jones. We will continue to do so until June $8^{\text {th }}$. Polls across the board remain volatile. However, as on the doorstep, it seems that people are responding well to our positive vision for Wales, and rejecting the Tory plans for more cruel cuts. ${ }^{5}$

12 And finally, on 7 June, i.e. the day just before polling day, a YouGov poll for ITV Wales and Cardiff University confirmed the Welsh Labour lead in Wales. ${ }^{6}$ Professor Scully commented that the latest polls showed a "revival in the fortunes of the Welsh Labour party ". In a blog post, he emphasized the dramatic U-turn in voters' intentions in Wales over the course of a few weeks: "This has been an erratic election in Wales: the first two polls of the campaign showed clear Conservative leads, and indicated that the Tories were on course for an historic electoral breakthrough. But our last poll indicated a dramatic Labour fightback. Labour support has apparently surged".

13 I have concentrated my analysis on the two main parties in Wales, Welsh Labour and the Welsh Conservatives, but the different polls reveal the smaller parties, Plaid Cymru and the LibDems, were squeezed by the media focus on May versus Corbyn. Considering those results, it is worth studying the position of Welsh Labour, focusing first on the role and position of party leaders, especially the prominent role played by Carwyn Jones, and second on the strategy implemented, as illustrated by the two main parties' manifestos. 


\section{Carwyn Jones's prominent role}

14

Carwyn Jones was, before, polling day in a powerful position since he had been the most senior Labour politician since 2010, being even re-elected First Minister in 2011 with his party winning 30 seats, hence being able to govern without a coalition, and again last year following the May 2016 Welsh elections, albeit after two votes in the Assembly. He has been leading a party with a majority ever since 2011. It is necessary to add that there has been a Labour First Minister in Wales ever since the creation of the Assembly and the first Welsh elections in 1999, even if the Labour Party had to form coalitions twice, in 2000 with the LibDems and between 2007 and 2011 with Plaid Cymru.

15 Jones is a very popular politician: a poll jointly conducted by the Wales Governance Centre and ITV in March 2015, i.e. a few weeks before the previous general election, revealed he was the most popular Welsh political leader. ${ }^{7}$ It was thus extremely surprising that Welsh Labour did not rely on him more during the 2015 campaign, as indicated by Roger Scully: “I don't quite understand why the Labour party in Wales doesn't use Carwyn Jones more in elections. If I was in the Labour party I would try to make sure he was front and centre in election campaigns". ${ }^{8}$ This may be explained by the fact that Carwyn Jones was a much less visible leader and First Minister than Rhodri Morgan before him, adopting a different style of leadership. An article published on 27 June 2014 was even entitled "Carwyn who? Poll findings reveal Welsh leaders significantly less known among Welsh voters than UK leaders". Graham Henry was commenting on the findings of a poll carried out by YouGov for Cardiff University's Wales Governance Centre between 2 and 15 June 2014 on 2,270 adults. ${ }^{9}$ The poll revealed that a proportion of Welsh voters did not know who Carwyn Jones was since $22 \%$ of respondents chose "Don't know" for Welsh Labour leader Carwyn Jones when asked to assess leaders on a scale of 1-10 on how they liked them. Graham Henry considered they chose that answer because they did not know who Carwyn Jones was... Professor Roger Scully played down such an interpretation:

Despite having been First Minister for four and a half years, Carwyn seems to be significantly more anonymous with the people of Wales. But Carwyn, in turn, is far more well-known to the Welsh public than the three opposition leaders in the Assembly, none of whom have seen their public profile increase significantly over the last 11 months. ${ }^{10}$

Nevertheless, the poll also indicated that Carwyn Jones was still the most popular party leader in Wales since he came first with 4.6/10, before Leanne Wood (4/10) and Kirsty Williams (3.9/10). Ed Miliband, the most popular leader for Westminster, came fourth (3.7/10). ${ }^{11}$ According to a Welsh Labour spokesman: "He [Carwyn Jones] was elected on a promise to be a Welsh Labour leader for the whole of Wales, and these figures show that he is clearly honouring that promise". ${ }^{12}$ And yet, he played a prominent role in the 2017 campaign.

\section{A fight between two leaders: Jones vs May}

During the general election campaign, Wales faced a paradoxical situation since the Conservative campaign centred on Theresa May, the British Prime Minister, which was rather logical considering she was a politician in power, while the Welsh Labour campaign focused on Carwyn Jones, the Welsh First Minister, also a leading politician, but

Revue Française de Civilisation Britannique, XXIII-2 | 2018 
not supposed to lead the Labour campaign, and not on Jeremy Corbyn, the British Labour leader. In other words, the Conservatives relied on a Britain-wide figure while Labour promoted its Welsh credentials. As illustrated by the launching of the two parties' manifestos: the Labour manifesto was launched by Carwyn Jones in Flintshire whereas it was Theresa May, and not Andrew RT Davies, the leader of the Welsh Conservatives, who launched the Welsh Conservative manifesto in Wrexham. She even made a visit to Bridgend, which was seen as a provocation since that is Carwyn Jones's constituency She seemed to consider the Conservatives would win the seat.

Having a look at the two parties' manifestos is instructive about their differing strategies. The front page of the Welsh Labour manifesto, Standing Up for Wales, shows Carwyn Jones and a child, whereas that of the Welsh Conservative manifesto, Forward Together: Our Plan for a Stronger Wales, a Stronger Britain and a Prosperous Future, has no image, the first photo comes on the second page and it represents Theresa May, standing in the middle, accompanied with Andrew RT Davies and Alun Cairns, the Secretary of State for Wales. On top of that, Welsh voters were clearly invited to vote for Theresa May, and not for Welsh MPs: "That is why, at this election, we ask you to vote for Theresa May and her Conservative team on $8^{\text {th }}$ June". ${ }^{13}$

Last, but not least, the Welsh Labour manifesto starts with a foreword written by Carwyn Jones whereas the Conservative one opens with Theresa May's words, the same as in the British manifesto. But it can be doubted whether such strategy was the right one for the Conservatives, since May's approval ratings were going down during the campaign, as indicated by Professor Roger Scully who was commenting on 1 June upon the latest poll results in Wales:

Meanwhile, the Conservatives' emphasis on leadership may also be much less of an advantage than it was: Theresa May's poll ratings have slipped significantly in the course of the campaign, while the popularity of Jeremy Corbyn has risen. The May versus Corbyn contrast that the Conservatives have sought to make central to the campaign could be working much less well for them now than it was doing. ${ }^{14}$

It worked even less in Wales since the contrast was between May and Jones, who had led the country since December 2009.

\section{7 vs 2015}

21 For this campaign, Carwyn Jones was given a prominent role by the Labour Party in Wales, especially in June, as indicated by Daniel Davies, the BBC political correspondent, who considered that the general election was "Welsh Labour's Goldilocks poll", after the title of his article on BBC Wales on 9 June 2017: "First Minister Mr Jones played the starring role in his party's Welsh campaign. Mr Corbyn wasn't airbrushed out completely, but it was telling that in a speech to launch the campaign Mr Jones did not mention Jeremy once". ${ }^{15}$ His image as a successful governing politician was an asset to be exploited by the Labour Party. There was first awkwardness between the two leaders, Carwyn Jones and Jeremy Corbyn, a feeling palpable during Corbyn's visit in Cardiff North during the first week of the campaign, when they had a rally together, and also at a moment when a poll forecast a Conservative victory in Wales for the first time since the 1850s. Corbyn was indeed at first viewed as a liability for Welsh Labour, as in 2016 for the Welsh elections, during which Corbyn never came to Wales. ${ }^{16}$ But their relationship was different in the 2017 campaign, especially in June, when visits by Corbyn were highly advertised on social networks, such 
as his visit to North Wales the day just before the general election, the day after Theresa May's almost secret visit to Wales, on 6 June. Indeed, she came to meet farmers, but hardly announced she was coming.

Besides, at the beginning of the campaign, in early May, Carwyn Jones was ready to stress the specific identity of Welsh Labour, to clearly distinguish their ideology from the London headquarters: "We must now refocus and fight a general election campaign the same way we always fight elections - with our own Welsh Labour values, huge amounts of hard work and an absolute commitment to stand up for our communities against the Tories". ${ }^{17} \mathrm{He}$ insisted on showing Welsh Labour had its own identity.

Such a strategic change between the 2015 and 2017 general elections can be explained by the increased renown of the Welsh First Minister. Since the Brexit referendum in June 2016, Carwyn Jones has gained more visibility and become a strong voice in the negotiations, defending Welsh devolution and Wales' interests. He was first strongly heard during the debates around the Wales Act 2017, eventually adopted in January 2017. Indeed, he stressed the British government's reluctance to expand devolution even if Parliament passed an act granting Wales the reserved powers model, as in Scotland: an appendix indicates the long list of more than 200 reservations. The issue was raised on 28 October 2016 by the House of Lords Constitutional Committee, who published its report on the bill. Its chairman, Lord Lang of Lonkton highlighted how it might actually reduce the powers of the Assembly: "The Bill risks, in some areas, actually reducing the powers of the Assembly. We have asked the government whether that was their intention, and if not, how they intend to avoid unintentionally diminishing the Assembly's powers". ${ }^{18}$ The extensive list of reservations might, according to him, lead to "confusion and legal uncertainty", hence " increased litigation" in courts between the British and Welsh institutions. ${ }^{19}$ Carwyn Jones regretted that the British Parliament did not take into consideration the alternative bill he had presented in March 2016, the Government and Laws in Wales Bill. He was supported by Leanne Wood, Plaid Cymru's president, who urged her party's AMs to reject the bill in the Assembly, as stressed by Dai Lloyd, the leader of Plaid Cymru's group: "This is an undemocratic bill which represents a significant roll-back of powers. Plaid Cymru cannot, in good conscience, support a bill which undermines the democratic will of people in Wales who voted for more powers in the 2011 referendum". ${ }^{20}$ The First Minister has also been extremely visible insisting on the fact the repatriation of powers from the European Union should not be taken by London as an opportunity to grab powers back from the Assembly. Many powers currently held in Brussels concern devolved matters, as farming or the environment. Theresa May announced these powers would be first repatriated in London, and later handed to the devolved administrations.

Furthermore, in Brexit, Devolution and the Changing Union: 2018, a pamphlet published in February 2018 by Lord David Owen, Gwynoro Jones, Lord Elystan Morgan and Glyndwr Cennydd Jones, Lord Morgan stressed it was necessary to set up "a UK-wide constitutional convention, with involvement of all parties and elements of British society to discuss the future of Union, particularly in the context of Brexit". ${ }^{21}$ If not initiated by the Conservative government, it should be created, they said, by the Labour Party, also including academics, to give it it more credibility, as underlined by Lord Owen:

If the Prime Minister herself does not embrace an all-party convention then the Labour Party and the SNP should forge an initial agreement, with the aim of building a cross-party convention capable of involving others. While it would be unfortunate not to have the assistance of Whitehall, the effects of this can be negated by the use of academics, thereby ensuring the quality of the convention. ${ }^{22}$ 
26

is exactly what Carwyn Jones did when he held a meeting in Cardiff on 29 March 2017, on the very day Theresa May triggered article 50 of the Lisbon Treaty, hence starting the Brexit process. It allowed him to launch a Labour constitutional convention. He invited members of the Labour Party including Gordon Brown, the former Prime Minister, John Prescott, the former Deputy Prime Minister, Kezia Dugdale, the Scottish Labour Party leader and MSP, and Jon Trickett, chair of the party's Campaign and Election Strategy. Besides, Jones held the meeting in the Wales Governance Centre, in Cardiff University, thus associating academics. As a result, Jones came to be the voice of Labour, along with Corbyn, and made Welsh Labour the real party of Wales.

\section{Welsh Labour, the real party of Wales}

\section{A party in power}

The success met by Welsh Labour was stressed from the very beginning of their manifesto, in the foreword: "Welsh Labour is in power in Wales and we want to establish a real partnership with a UK Labour government", ${ }^{23}$ hence giving the impression that in this partnership with London, Cardiff would be the senior partner, and not the other way round. The British Labour Party was seeking to be back in power, after seven years in opposition, while Welsh Labour had been in office for nearly 20 years in Wales, ever since the opening of the Assembly and the first elections. A key expression in this 113-page document is "the Welsh Labour Government", with a clear assessment of the past few years and the policies implemented in Wales by Carwyn Jones's government, through the use in the whole manifesto of present perfect forms or -ing forms describing current policies. On the contrary, a UK Labour government is a government to be, hence the use of "will" and the multiplication of pledges. British Labour could make no assessment of its own record, after seven years as the Opposition in Westminster. Welsh Labour was thus in a powerful position, as indicated on page 96: "We are proud of the achievements of the Welsh Labour Government and its record of delivery". ${ }^{24}$

This was in clear opposition with the Welsh Conservatives' manifesto, the title of which underlines its double anchoring: Our Plan for a Stronger Wales, a Stronger Britain..., hence showing the extent to which it was a more British-centred manifesto, with a real emphasis on Britain, more than Wales. The Conservative manifesto restated many of the pledges made at a UK level, along with pledges for the 2021 assembly elections.

Welsh Labour's domination of the Assembly also reveals the weaknesses of the major opposition parties. Indeed, Welsh Labour's performance in economy, health or education is usually regarded as relatively poor and disappointing, and yet the party has managed to remain the dominant one in the country: "What seems rather extraordinary is that negative perceptions of Labour's performance in government in Wales do not seem have cost Labour much, if any electoral support". ${ }^{25}$ Roger Scully considers this is mostly due to the failure of non-Labour political parties in Wales which have not managed to present themselves as reliable and convincing alternatives.

\section{A Brexit election}

Theresa May called for an early general election to strengthen her position as the Brexit Prime Minister, following the June 2016 referendum. That is why she decided to focus the 
campaign on the issue and to make this a Brexit election, as clearly indicated in the first lines of the foreword jointly written by Andrew RT Davies and Alun Cairns: "The choice facing the people of Wales in this election is all about the future. Whoever wins the election will face one overriding task to get the right deal for Wales, and for the whole of the UK, from our exit from the $E U " .{ }^{26}$ Since Wales had voted in its majority in favour of Brexit the previous year, the British PM was confident her party would be successful in the country and the vote came to be a vote for her more than for her party.

It seemed at first to be the right strategy, as stressed on 1 June by Professor Scully: “ However, the Tories retain one considerable strength: voters still rank Brexit as the most important issue in the election, and rate the Conservatives as the best party to deal with this issue". ${ }^{27}$ The final Welsh poll, asking the sample about the most important issues in the election, showed that Brexit was the priority for $50 \%$ of people in Wales, but health, albeit a devolved issue, came second, immigration third and the economy fourth. This should have helped the Conservatives, especially since the end of May poll had indicated that for $32 \%$ of Welsh people the Conservatives were the party best able to handle Brexit. ${ }^{28}$

Such a strategy was afterwards analysed as faulty by members of the Welsh Conservative Party, such as Preseli Pembrokeshire MP Stephen Crabb, former Secretary of State for Wales, who maintained that the motivation for holding an election ahead of the start of Brexit negotiations in 2018 had been "entirely right and proper". Yet, he added:

Clearly something has gone wrong because the country has wanted to talk about other issues at this election time. They wanted to raise other concerns and there are a whole lot of new voters who were less concerned about Brexit and more concerned about issues to do with quality of life and their economic security in the future. $^{29}$

In contrast, Welsh Labour decided to widen the debate and to focus on other issues, everyday ones, such as education, health, or economy, some of which were devolved and all of which were examined from a Welsh point of view, stressing Labour's achievements. Carwyn Jones differentiated the Brexit negotiations and the general election campaign. This strategy was stressed very early in the manifesto: "This is not a Brexit election" ${ }^{30}$ The approach proved to be a key to success, as it had been in February 1974 when Edward Heath, the Conservative PM who had called the snap election to solve his disputes with the miners, restricted debates to "Who runs the country?" whereas Harold Wilson, the Labour leader, chose to widen issues, also dealing with inflation and jobs. As a result, Welsh Labour published a specifically Welsh manifesto, which was a new strategy introduced by Rhodri Morgan for the 2003 Welsh elections. At the time, the Welsh Labour leader and First Minister explained:

Provided we could distinguish our style of government from the new frontiers of New Labour in Westminster, I thought we could reach the first re-elections to the Assembly in reasonable shape. [...] When it came down to writing the manifesto for May 2003, Welsh Labour's own policy-making machinery had produced some workmanlike sets of proposals. ${ }^{31}$

The Welsh Labour manifesto had obviously been written in Wales, reasserting pledges made the previous year and restating existing policies introduced by Cardiff Bay, especially in devolved areas. This was the case for instance in health, the party claiming that Welsh Labour had "defended the Welsh NHS from Conservative attacks and from a disruptive top-down reorganisation". ${ }^{32}$ Or in education since, according to Welsh Labour, under Carwyn Jones's leadership there had been "new momentum in Welsh education. The policies introduced by successive Welsh Labour governments have raised standards for all" ${ }^{33}$ 


\title{
Conclusion
}

35

\begin{abstract}
especially in allowing the leader Carwyn Jones, First Minister since December 2009, to play a prominent role in the campaign, being much more visible than two years before. If the fight was between May and Corbyn in Britain, it was between May and Jones, two governing leaders, in Wales. Furthermore, the Welsh Labour Party was able to present itself as the real party of Wales, a title usually claimed by Plaid Cymru, which did not manage to make itself heard. It clearly presented itself as a party in power, insisting on its previous achievements, and decided to widen the debates, limited to Brexit by the Conservative Party. Considering the very good results obtained in Wales, the Welsh Labour Party can be regarded as a model for Labour in general. Its success story will allow Carwyn Jones to play an important role in the Brexit negotiations, as indicated by his numerous calls and warnings to the British government, as on 19 July 2017, following the publication of the EU Committee (House of Lords) 's report on Brexit and Devolution, warning of potential risks to Welsh agriculture and manufacturing. As Carwyn Jones said: "We have repeatedly tried to engage with the UK government and have put forward constructive proposals about how we can deliver a Brexit which honours the result of the referendum, safeguards the economy and respects devolution". ${ }^{34}$ Such a statement heralds an on-going struggle between Cardiff and London.
\end{abstract}

polls and to win the general election. This was thanks to its campaigning strategy,

\section{BIBLIOGRAPHY}

Anon, BBC News, “Poll: Carwyn Jones's rating slips but he stays in front”, BBC, 27-06-2014, http:// www.bbc.com/news/uk-wales-politics-28057489, accessed May 2016.

Anon, “GE 2017: How the parties fared in Wales”, BBC Wales, 08-06-2017, http://www.bbc.com/ news/av/uk-wales-40218554/general-election-2017-how-the-parties-fared-in-wales, accessed July 2017.

Anon, “General Election 2017: Labour hails 'fantastic' results”, BBC Wales, 09-06-2017, http:// www.bbc.com/news/uk-wales-politics-40195154, accessed in September 2017.

Anon, "UK government warned over Brexit and Wales by peers", BBC Wales, 19-07-2017, http:// www.bbc.com/news/uk-wales-politics-40645038, accessed in October 2017.

Bory, Stéphanie, “From Rhodri Morgan to Carwyn Jones, two different styles of leadership", in L'Observatoire de la société britannique, n²0, January 2018.

Davies, Daniel, “Was this Welsh Labour's Goldilocks poll?”, BBC Wales, 09-06-2017, http:// www.bbc.com/news/election-2017-40215011, accessed September 2017.

Deans, David, “First Minister Carwyn Jones remains as Wales' most popular political leader, according to a new opinion poll”, www.walesonline.co.uk, , 23-03-2015, accessed May 2016.

Revue Française de Civilisation Britannique, XXIII-2 | 2018 
Foster, Alice, "Who will win the election in Wales? Latest Welsh opinion polls for general election”, The Daily Express, 07-06-2017, http://www.express.co.uk/news/politics/812337/ election-polls-who-will-win-in-Wales-latest-Welsh-opinion-poll-Labour-Conservatives, accessed September 2017.

Hayward, Will, "The House of Lords' scathing report on the UK Government's plans for devolution to Wales", WalesOnline, 28-10-2016, http://www.walesonline.co.uk/news/politics/ house-lords-scathing-report-uk-12092209, accessed January 2017.

Henry, Graham, "Carwyn who? Poll findings reveal Welsh leaders significantly less known among Welsh voters than UK leaders", WalesOnline, 27-06-2014, http://walesonline.co.uk/news/walesnews/carwyn-who-poll-findings-reveal-7333198, accessed February 2016.

Jones, Glyndwr Cennydd, Jones, Gwynoro, Morgan, Elystan \& Owen, David, Brexit, Devolution and the Changing Union: 2018 (Cardiff, IWA, 2018).

Milne, Oliver, "The Wales Bill is now law - here's what it means", 31-01-2017, http:// www.walesonline.co.uk/news/politics/wales-bill-now-law, accessed February 2017.

Morgan, Rhodri, Rhodri, A Political Life in Wales and Westminster (Cardiff, University of Wales Press, 2017).

Morris, Steven, "Welsh Labour leader denies banning Corbyn from campaign trail”, The Guardian, 29-04-2016, https://www.theguardian.com/politics/2016/apr/29/welsh-labour-leader-carwynjones-denies-banning-jeremy-corbyn-wales-ken-livingstone, accessed May 2016.

Morris, Steven, "Welsh Labour to distance itself from UK party in general election", The Guardian, 05-05-2017, https://www.theguardian.com/politics/2017/may/05/welsh-labour-distance-itselfuk-party-corbyn-general-election, accessed June 2017.

Scully, Roger, "Ernie Wise and Welsh politics", 24-02-2014, http://blogs.cardiff.ac.uk/ electionsinwales/2014/02/24/ernie-wise-and-welsh-politics/, accessed in February 2017.

Scully, Roger, “The latest Welsh General Election Poll”, 08-05-2017, http://blogs.cardiff.ac.uk/ electionsinwales/2017/05/08/the-latest-welsh-general-election-poll/, accessed September 2017.

Shipton, Martin, "Shock poll puts the Conservatives ahead of Labour in Wales", WalesOnline, 24-04-2017, http://www.walesonline.co.uk/news/politics/shock-poll-puts-conservativesahead-12937740, accessed September 2017.

Shipton, Martin, "This is the latest General Election poll for Wales as Labour surges ahead", WalesOnline, 22-05-2017, http://www.walesonline.co.uk/news/politics/latest-general-electionpoll-wales-13073791, accessed September 2017

Shipton, Martin, "What the latest General Election poll in Wales shows about the parties' hopes", WalesOnline, 01-06-2017, http://www.walesonline.co.uk/news/politics/what-latest-generalelection-poll-13124475, accessed September 2017.

Welsh Conservatives, Forward Together: Our Plan for a Stronger Wales, a Stronger Britain and a Prosperous Future (Cardiff, Welsh Conservative Party, 2017).

Welsh Labour, Standing Up for Wales (Cardiff, Welsh Labour Party, 2017).

\section{NOTES}

1. “GE 2017: How the parties fared in Wales", BBC Wales, 08-06-2017, http://www.bbc.com/news/ av/uk-wales-40218554/general-election-2017-how-the-parties-fared-in-wales, accessed July 2017. 
2. Martin Shipton, "Shock poll puts the Conservatives ahead of Labour in Wales", WalesOnline, 24-04-2017, http://www.walesonline.co.uk/news/politics/shock-poll-puts-conservativesahead-12937740, accessed September 2017.

3. Professor Scully, "The latest Welsh General Election Poll”, 08-05-2017, http:// blogs.cardiff.ac.uk/electionsinwales/2017/05/08/the-latest-welsh-general-election-poll/, accessed September 2017.

4. Martin Shipton, "This is the latest General Election poll for Wales as Labour surges ahead", WalesOnline, 22-05-2017, http://www.walesonline.co.uk/news/politics/latest-general-electionpoll-wales-13073791, accessed September 2017

5. Martin Shipton, "What the latest General Election poll in Wales shows about the parties' hopes", WalesOnline, 01-06-2017, http://www.walesonline.co.uk/news/politics/what-latestgeneral-election-poll-13124475, accessed September 2017.

6. Alice Foster, "Who will win the election in Wales? Latest Welsh opinion polls for general election", The Daily Express, 07-06-2017, http://www.express.co.uk/news/politics/812337/ election-polls-who-will-win-in-Wales-latest-Welsh-opinion-poll-Labour-Conservatives, accessed September 2017.

7. David Deans, “First Minister Carwyn Jones remains as Wales' most popular political leader, according to a new opinion poll”, www.walesonline.co.uk, , 23-03-2015, accessed May 2016.

8. Ibid.

9. Graham Henry, "Carwyn who? Poll findings reveal Welsh leaders significantly less known among Welsh voters than UK leaders", 27-06-2014, http://walesonline.co.uk/news/wales-news/ carwyn-who-poll-findings-reveal-7333198, accessed February 2016. For more details, see Stéphanie Bory, "From Rhodri Morgan to Carwyn Jones, two different styles of leadership", in L'Observatoire de la société britannique, $\mathrm{n}^{\circ} 20$, January 2018.

10. Professor Roger Scully, in Graham Henry, "Carwyn who?", op. cit.

11. BBC News, "Poll: Carwyn Jones's rating slips but he stays in front", BBC, 27-06-2014, http:// www.bbc.com/news/uk-wales-politics-28057489, accessed May 2016.

12. Ibid.

13. Welsh Conservatives, Forward Together: Our Plan for a Stronger Wales, a Stronger Britain and a Prosperous Future (Cardiff, Welsh Conservative Party, 2017), p. 7.

14. Roger Scully, in Martin Shipton, op. cit.

15. Daniel Davies, “Was this Welsh Labour's Goldilocks poll?”, BBC Wales, 09-06-2017, http:// www.bbc.com/news/election-2017-40215011, accessed September 2017.

16. Steven Morris, "Welsh Labour leader denies banning Corbyn from campaign trail", The Guardian, 29-04-2016, https://www.theguardian.com/politics/2016/apr/29/welsh-labour-leadercarwyn-jones-denies-banning-jeremy-corbyn-wales-ken-livingstone, accessed May 2016.

17. Carwyn Jones, in Steven Morris, "Welsh Labour to distance itself from UK party in general election”, 05-05-2017, https://www.theguardian.com/politics/2017/may/05/welsh-labourdistance-itself-uk-party-corbyn-general-election, accessed June 2017.

18. House of Lords Constitutional Committee, in Will Hayward, "The House of Lords' scathing report on the UK Government's plans for devolution to Wales", 28-10-2016, http:// www.walesonline.co.uk/news/politics/house-lords-scathing-report-uk-12092209, accessed January 2017.

19. Ibid.

20. Dai Lloyd, in Oliver Milne, "The Wales Bill is now law - here's what it means", 31-01-2017, http://www.walesonline.co.uk/news/politics/wales-bill-now-law, accessed February 2017.

21. Lord Elystan Morgan, in Lord David Owen, Gwynoro Jones, Lord Elystan Morgan \& Glyndwr Cennydd Jones Brexit, Devolution and the Changing Union: 2018 (Cardiff, 2018), p. 2

22. Lord David Owen, "A Federal Framework", in Lord David Owen, Gwynoro Jones, Lord Elystan Morgan \& Glyndwr Cennydd Jones, op. cit., p. 5. 
23. Welsh Labour, Standing Up for Wales (Cardiff, Welsh Labour Party, 2017), p. 3.

24. Ibid., p. 96.

25. Roger Scully, "Ernie Wise and Welsh politics", 24-02-2014, http://blogs.cardiff.ac.uk/ electionsinwales/2014/02/24/ernie-wise-and-welsh-politics/, accessed in February 2017.

26. Welsh Conservatives, op. cit., p. 6.

27. Roger Scully, in Martin Shipton, op. cit.

28. Martin Shipton, op. cit.

29. Stephen Crabb, in "General Election 2017: Labour hails 'fantastic' results", BBC Wales, 09-06-2017, http://www.bbc.com/news/uk-wales-politics-40195154, accessed in September 2017.

30. Welsh Labour, op. cit., p. 7.

31. Rhodri Morgan, Rhodri, A Political Life in Wales and Westminster (Cardiff, University of Wales Press, 2017), p. 255.

32. Welsh Labour, op. cit., p. 63.

33. Ibid., p. 31.

34. BBC Wales, "UK government warned over Brexit and Wales by peers", 19-07-2017, http:// www.bbc.com/news/uk-wales-politics-40645038, accessed in October 2017.

\section{ABSTRACTS}

General elections offer opportunities to study Britain's political life, in particular the position and strength of each party in the four nations which make up the United Kingdom. The Labour Party has dominated the Welsh political landscape for decades now and the June 2017 snap election was no exception. Welsh Labour obtained good results, mainly thanks to the prominent role given to Carwyn Jones, First Minister and leader of the party. He adopted an ambivalent attitude: he was extremely visible on the question Brexit but he refused to limit campaign debates to this issue.

Les élections législatives britanniques permettent d'étudier la vie politique ainsi que les rapports de force entre les différents partis dans les quatre nations constitutives du Royaume-Uni. La scène politique galloise est dominée par le Parti travailliste depuis des décennies et les élections anticipées de juin 2017 ont confirmé cette position privilégiée. Les Travaillistes gallois ont obtenu de très bons résultats au pays de Galles, meilleurs que dans le reste du Royaume-Uni, en grande partie grâce à Carwyn Jones, First Minister et chef du parti, qui a joué un rôle central dans la campagne. Celui-ci a en effet adopté une stratégie ambivalente, étant particulièrement visible au cours des discussions sur le Brexit tout en refusant de faire de cette question le seul sujet de la campagne.

\section{INDEX}

Mots-clés: élections législatives, Pays de Galles, Parti travailliste gallois, Carwyn Jones Keywords: general election, Wales, Welsh Labour, Carwyn Jones 


\section{AUTHOR}

\section{STÉPHANIE BORY}

Institut d'Etudes Transtextuelles et Transculturelles (IETT), EA 4186, Université Jean Moulin Lyon 3 